\title{
nature
} medicine

\section{More good than harm}

The manner in which President George W. Bush came to hold the office of the 43rd President of the United States-not on a majority vote but on a technicality-left him wide open to criticism of his ability to unify and lead the most powerful country in the world. Most people anticipating his first address to the nation since his inauguration were scathing in their predictions of its outcome. But on 9 August as he appeared on TV and meandered his way through an explanation of the issues surrounding human embryonic stem (ES)-cell research, he arrived at a conclusion almost worthy of Solomon. Despite reports in the lay press decrying his judgment, it is one that serves the biomedical community in the US well-at least for the short term.

Bush's decision rests on a 9 August watershed. He will allow federal funding for research on human ES-cell lines that were in existence by that date because his administration had no power over the destruction of the embryos involved; but he will not condone the use of government money for research on cell lines made after this time since this would sanction the death of additional embryos.

This decision is a positive one for scientists working in the discipline on several fronts. Importantly, it legitimizes their field of research for the first time. Rather than having to conduct their experiments behind closed doors with private funds, the policy makes their work official-the US government now acknowledges their research. This change in status leads to a second benefit for the scientific community: new research funds will now be made available for this work, to be distributed by the National Institutes of Health $(\mathrm{NIH})$, the largest biomedical sponsor in the country.

Another advantage is that an NIH audit ordered by Bush while he was being briefed on the science behind the field has uncovered as many as 60 existing human ES-cell lines worldwide. This number has sur- prised all scientists, as the consensus had been that only a dozen lines had been derived. Thus, Bush's consideration of the subject has served to enlighten the research community.

But as with all complicated issues, no decision is perfect, and it is the restriction of funding for these 60 cell lines alone that presents the biggest and most immediate problem. Research into mouse ES cells has been taking place for almost 20 years, yet there are only five lines in use. This is not because only five lines have been tried, but because only these lines have proven viable. Compare this with the nascent field of human ES cells, which can be read in roughly eight published papers; it is clear that there has not yet been the time, funding or manpower to optimize culture conditions for human cells. So scientists' concerns about the quality of the 60 lines that will be approved for use on the government registry are serious and understandable.

Another shortcoming is that because only 60 cell lines have made it onto the approved list, these will become a prized commodity and their market value will increase. Laboratories lucky enough to hold a set of the chosen lines could choose to levy hefty charges for their use and draw up complicated material transfer and licensing agreements to profit from any downstream discoveries. Early signs hint that this may happen, namely the legal suit filed on 13 August by the U of WisconsinMadison, against California-based licensee Geron over commercial rights to its patented cell lines, which can be obtained via WiCell for $\$ 5,000$.

Even when cell lines are held in academic labs and controlled by researchers who favor simple collaborative agreements, these facilities are outside the US in countries such as Australia, Singapore and Israel, introducing problems of geographical transfer into the equation.
But to dwell on these problems at this time seems churlish. Given that six months ago the research community believed Bush would ban federal funding for this type of research altogether, thus consigning it to the same private clinic fate as in vitro fertilization research in the US, scientists will seize the moment-and the money-to move the human ES-cell field forward.

Of course, the US research environment is nowhere near as accommodating as that in the United Kingdom, but even that shortfall could be viewed in a positive light. There is much fundamental research still to be done and, as evident in fields such as gene therapy, forging ahead into clinical trials before approaches are validated in animal models can do a field of research more harm than good. Laying the solid groundwork and establishing underlying scientific principles in ES-cell research should serve science well in the longer term.

Scientists must validate the approved cell lines, gather data on their biology, and then through basic research go on to prove that human ES cells can indeed deliver on their much-publicized medical promise. In addition to their potential role in regenerative medicine, ES cells are a powerful tool for fundamental studies of human development, functional genomics in man, and the discovery and testing of protein and small-molecule therapeutic agents.

By demonstrating that these cells can be made to differentiate into tissue with a true capacity to cure disease, scientists will win the full backing of the US public, leading to demands for increased research through lobbying Congress and pressurizing the incumbent administration to expand upon the Bush policy. But that is for the future, and for now it is sufficient to say that to have expected anything more from a leader elected on a conservative, anti-abortion platform was unrealistic. The Bush decision is something of a victory for medical research. 